\title{
Generational Differences in Personal Finance Behaviour - A Insight into Investors in Kolkata
}

\author{
Risav Adhikari, Shiwangi Poddar
}

\begin{abstract}
Purpose - Similar experiences, values and beliefs shared among people of a generational cohort determines the choices that they make. This explains why people of the same generational cohort have distinct perceptions and tendencies towards investing. This paper focuses on generation differences in personal finance decisions. Objectives- The objective of the paper is to group the different personal finance variables into identifiable factors and to compare these personal finance factors across generations. Methodology - Data is collected through a primary survey with a structured questionnaire, among 140 respondents in Kolkata and Ranchi. Questions have been asked on personal finance behaviour, with their responses on a Likert scale. A Factor Analysis has been conducted on these questions to group them into different factors contributing to personal finance behaviour. These identified factors are also compared across generations. Findings - It was concluded that younger generations invest for the objective of keeping funds for emergency purposes, whereas older generations invest for their retirement needs. Younger generations usually invest for the short run, whereas older generations invest for the long run. Also, younger generations invest in easily accessible and popular investment avenues, whereas older invest in the most effective avenue. The items had clustered around six factors namely, Financial Planning, Use of Technology, Financial Independence, Financial Irresponsibility, Financial Openness and Use of Credit Cards. Originality- Behavioral differences across generations is an area that is studied across diverse topics and disciplines. However, very scarce studies have been conducted to assess generational differences in financial behaviour. Practical Implications- This paper attempts to bridge this gap by collecting financial data from respondents of all generations and making a comparison among them. This helps to understand the reasons for differences in investment behaviour of generations.
\end{abstract}

Keywords: Personal Finance, Generational Cohort, Finance across Generations, Generational Differences

\section{INTRODUCTION}

Individuals of a generation share the same economic, social and political events during their lives that develops a similar set of values, beliefs and behaviour. This gives rise to every generation possessing some unique characteristics, different from that of previous generations. This concept is proposed by the generational cohort theory.

Manuscript received on 15 October 2021 | Revised Manuscript received on 27 October 2021 | Manuscript Accepted on 15 November 2021 | Manuscript published on 30 November 2021. * Correspondence Author

Risav Adhikari*, Faculty Member in Management, St. Xavier's University, Kolkata (West Bengal), India.

Shiwangi Poddar, Faculty Member in Management, at St. Xavier's University, Kolkata (West Bengal), India.

(C) The Authors. Published by Lattice Science Publication (LSP). This is an open access article under the CC-BY-NC-ND license (http://creativecommons.org/licenses/by-nc-nd/4.0/)
Generational cohorts are a group of people who go through similar experiences while growing up. These groups share memories, life events and societal changes specific to their age group. Generational cohorts are usually classified into Baby Boomers (born from 1946-64), Generation X (born from 1965-80), Generation Y/Millennials (born from 1981-96) and Generation Z (born from 1997-2012).These similar experiences, values and beliefs shared among people of a generational cohort, in turn, determines the choices that they make. This would explain why people of the same generational cohort have distinct perceptions and tendencies towards investing.This paper would focus on generation differences in personal finance decisions. It would understand each generation's views on the importance of financial independence, financial planning, risk taking and the use of financial technology. It would also examine these same parameters for the each generation and compare them across the generations.

\section{LITERATURE REVIEW}

(Scheresberg \& Lusardi, 2014) talk about the financial capability, management and planning of Generation Y. For this purpose, a survey of more than 25000 Generation Y Americans was conducted. The study revealed Millennials have a check on their savings account, but majority of them do not have access to credit cards. Also their major source of debt was student loans.(Ameritrade, 2016) conducted this study to understand the spending and saving pattern of different generations. An online survey was conducted across 2100 Americans by Head Solutions Group on behalf of TD Ameritrade Corporation. It was found that Boomers perceive themselves more as savers than Millennials. More Millennials were found to use money budgets. Also Boomers were found to concentrate more on their financial goals (Bauer, Collins, \& Richardson, 2017) understand the attitude of Generation X and Millennials (Generation $\mathrm{Y}$ ) with respect to financial wealth, and try to find similarities and differences. Questions are asked on three parameters: risk taking, financial independence and trust of outsiders. ANOVA is conducted to find significant differences in two generations. They found that Millennials are financially more independent, they also take more risks, and lastly they tend to trust the advice of outsiders for financial decisions. (Kurz, Li, \& Vine, 2018) compare the socioeconomic characteristics on Millennials with those of previous generations. For this purpose, a survey was conducted to compare the consumption and savings pattern, while also accounting for the demographic variables.

Lattice Science Publication (LSP)

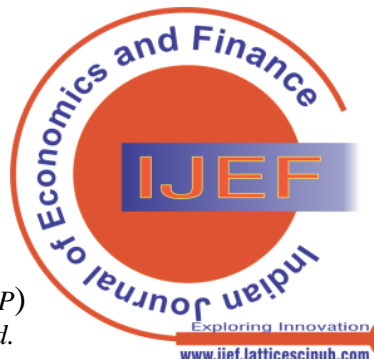




\section{Generational Differences in Personal Finance Behaviour - A Insight into Investors in Kolkata}

They found that Millennials are worse off than their previous generations when they were young, in terms of earning or assets. Also Millennials unlike their previous generations do not prefer consumption over saving. (Luther, Coleman, Kelkar, \& Foudray, 2018) find out the differences in perception towards financial planners among various generations. The study was conducted through a survey across all four generations, inquiring about the use of a financial planner, basis for selecting one and services sought. They concluded that Millennials and Generation X prefer financial planners, want more frequent communication with them, and also consider their advice more valuable. Carlin, Olafsson, \& Pagel, 2019) analyse transaction level individual data to see how different generations make personal finance decisions. To understand the same, they compare individual income, spending, account balances, credit limits and use of technology. The study found that older people tend to use more credit facilities and younger people adopt technology faster.(Carlin, Olafsson, \& Pagel, Fintech Adoption Across Generations: Financial Fitness in the Information Age, 2019) talk about the difference in adoption of financial technology across generations. This is understood through a survey which assesses the use of mobile applications for investment purposes. The study revealed that Millennials spend more on discretionary items as compared to Generation X. Also, younger generations saved fees and penalties due to the use of technology.(Deventer, 2020) aims to personal finance behaviour of Generation Y students, with respect to financial planning and various skills required to do so. For this study, he has taken a sample of 500 students from the Gauteng province in South Africa. The study showed that the students' actual financial behaviour and financial skill-sets present were highly correlated.(Horan, 2020) looks into how different generations spend their money. The study considers three generations: Millennials, Generation X and Baby Boomers and their spending patterns. It found that Generation $\mathrm{X}$ have the highest incomes and also do spend the most. Further housing and healthcare are the areas where people spend the most. Spending on housing decreased with age, whereas spending on healthcare increased with age.(Columbia ThreadNeedle Investments, 2020) try to understand why different generations approach financial decisions differently. This report is based on a survey of 2000 individuals in the United Kingdom, across three generations: Baby Boomers, Generation X and Millennials. The report found that Millennials are more worried about financial matters. Financial decisions of the younger generations were found to be influenced by the older generations. It concluded that younger generations invested less than older generations (Sulphey \& Faisal, 2020) aim this paper to find inter-generational differences in investment behaviour. In order to understand such differences, they have administered the ORTOFIN - Orientation Towards Finance among the different generations. Their study concluded that younger generations have access to more financial information, whereas older generations have better financial planning.

\section{RESEARCH GAP}

Behavioral differences across generations is an area that is studied across diverse topics and disciplines. However, very scarce studies have been conducted to assess generational differences in financial behaviour. There exists very limited literature to understand this phenomenon, of how generations vary in terms of financial independence, financial planning, risk taking or the use of financial technology.This paper attempts to bridge this gap by collecting financial data from respondents of all generations and making a comparison among them. The primary objective of this study would be to analyse this generational difference in financial behaviour.

\section{OBJECTIVES}

To group the different personal finance variables into identifiable factors. To compare these personal finance factors across generations.

\section{METHODOLOGY}

\section{A. Data Collection}

Data is collected through a primary survey with a structured questionnaire. Questions have been asked relating to the Income, Income Allocation, Purpose of Investment, Time Horizon for Investment and Investment Avenue. Further, 28 questions have been asked on personal finance behaviour, with their responses on a Likert scale.

\section{B. Sampling Design}

For the purpose of the study, a survey was conducted among respondents in Kolkata and Ranchi. A total of 140 respondents constitutes a sample for this study. Respondents are selected using convenience sampling.

\section{Tools Used}

Microsoft Excel is used to compile and code the data. SPSS is used to analyze it by performing tests on it.Firstly, the Income, Income Allocation, Purpose of Investment, Time Horizon for Investment and Investment Avenue have been compared across generations.Next, a Factor Analysis (Principal Component Analysis) has been conducted on the above mentioned 28 questions to group them into different factors contributing to personal finance behaviour. The score for each of these factors is computed and compared across generations, using means and cross-tabulations.

\section{ANALYSIS \& FINDINGS}

\section{A. Reliability Test}

For assessing the reliability, Cronbach's Alpha has been computed. A value of Cronbach's Alpha more than 0.7 signifies the data is reliable.In this case the value of Cronbach's Alpha is 0.937 , thus our data is excellent in terms of reliability. (Refer Table 1)

Table 1: Reliability Statistics

\begin{tabular}{|c|c|}
\hline Cronbach's Alpha & N of Items \\
\hline .937 & 28 \\
\hline
\end{tabular}

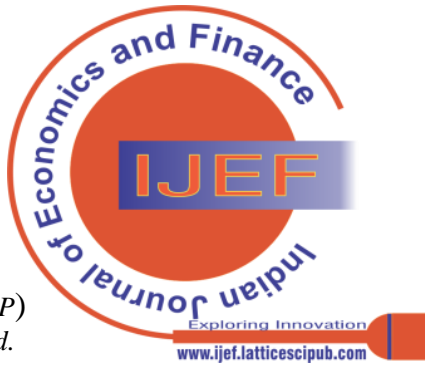




\section{B. Personal Finance Variables Across Generations}

- Purpose of Investment Across Generations: It can be observed that Generation Z's main purpose of investment is Emergencies. Generation Y invests for two purposes both Emergencies and Retirement Needs. Generation X mainly invests for Retirement Needs. This is due to the shift in needs with age. (Refer Table 2)

Table 2: Purpose of Investment * Generation Cross-tabulation

\begin{tabular}{|c|c|c|c|c|}
\hline \multicolumn{2}{|c|}{} & $\begin{array}{c}\text { Generatio } \\
\mathbf{n ~ Z}\end{array}$ & $\begin{array}{c}\text { Generatio } \\
\mathbf{n ~ Y}\end{array}$ & $\begin{array}{c}\text { Generati } \\
\text { on X }\end{array}$ \\
\hline \multirow{4}{*}{$\begin{array}{c}\text { Purpose of } \\
\text { Investmen } \\
\mathbf{t}\end{array}$} & $\begin{array}{c}\text { Medical } \\
\text { Needs }\end{array}$ & 6 & 6 & 2 \\
\cline { 2 - 5 } & Tax Saving & 5 & 7 & 0 \\
\cline { 2 - 5 } & $\begin{array}{c}\text { Retirement } \\
\text { Needs }\end{array}$ & 10 & $\mathbf{2 3}$ & $\mathbf{8}$ \\
\cline { 2 - 5 } & House & 4 & 14 & 2 \\
\cline { 2 - 5 } & $\begin{array}{c}\text { Children's } \\
\text { Needs }\end{array}$ & 1 & 3 & 3 \\
\cline { 2 - 5 } & Emergencies & $\mathbf{2 4}$ & $\mathbf{1 9}$ & 3 \\
\hline
\end{tabular}

- Time Horizon for Investment Across Generations: Generation Z can be seen to usually invest for 1-3 years. Generation Y usually invests for either 1-3 years or 3-5 years. Generation $\mathrm{X}$ is observed to usually invest for Above 10 years. From this we can understand that younger generations invest for the short run, whereas the older generations invest for the long run. (Refer Table 3)

Table 3: Time Horizon * Generation Cross-tabulation

\begin{tabular}{|c|l|c|c|c|}
\hline \multicolumn{2}{|c|}{} & $\begin{array}{c}\text { Generation } \\
\mathbf{Z}\end{array}$ & $\begin{array}{c}\text { Generation } \\
\text { Y }\end{array}$ & $\begin{array}{c}\text { Generation } \\
\mathbf{X}\end{array}$ \\
\hline \multirow{5}{*}{} & $\begin{array}{l}\text { Less } \\
\text { than } 1 \\
\text { year }\end{array}$ & 13 & 14 & 0 \\
\cline { 2 - 5 } Time \\
\begin{tabular}{c} 
Horizon \\
\cline { 2 - 5 }
\end{tabular} & $\begin{array}{l}1-3 \\
\text { years }\end{array}$ & $\mathbf{2 1}$ & $\mathbf{1 8}$ & 3 \\
\cline { 2 - 5 } & $\begin{array}{l}3-5 \\
\text { years }\end{array}$ & 6 & $\mathbf{1 7}$ & 1 \\
\cline { 2 - 5 } & $\begin{array}{l}5-10 \\
\text { years }\end{array}$ & 7 & 13 & 6 \\
\cline { 2 - 5 } & $\begin{array}{l}\text { Above } \\
10 \text { years }\end{array}$ & 3 & 10 & $\mathbf{8}$ \\
\hline
\end{tabular}

- Investment Avenue Across Generations: It can be seen here that Generation $\mathrm{Z}$ mostly invests in Fixed Deposits. Generation Y invests in either Fixed Deposits or Mutual Funds. Generation X, on the other hand, mostly invests Mutual Funds.it can be understood that younger generations choose more popular avenues for investment, whereas older generations are more experienced and thus choose more effective investment avenues. (Refer Table 4)

Table 4: Investment Avenue * Generation Cross-tabulation

\begin{tabular}{|c|l|c|c|c|}
\hline \multicolumn{2}{|c|}{} & $\begin{array}{c}\text { Generatio } \\
\text { n Z }\end{array}$ & $\begin{array}{c}\text { Generatio } \\
\text { n Y }\end{array}$ & $\begin{array}{c}\text { Generatio } \\
\text { n X }\end{array}$ \\
\hline \multirow{4}{*}{$\begin{array}{c}\text { Investment } \\
\text { Avenue }\end{array}$} & $\begin{array}{l}\text { Fixed } \\
\text { Deposit }\end{array}$ & $\mathbf{2 3}$ & $\mathbf{2 5}$ & $\mathbf{5}$ \\
\cline { 2 - 5 } & PPF & 5 & 13 & 0 \\
\cline { 2 - 5 } & $\begin{array}{l}\text { Mutual } \\
\text { Fund }\end{array}$ & 8 & $\mathbf{2 2}$ & $\mathbf{8}$ \\
\cline { 2 - 5 } & $\begin{array}{l}\text { Stock } \\
\text { Market }\end{array}$ & 8 & 6 & 1 \\
\cline { 2 - 5 } & Insurance & 4 & 3 & 2 \\
\cline { 2 - 5 } & Gold & 2 & 3 & 2 \\
\hline
\end{tabular}

- Income Utilization Across Generations

Housing \& Utilities - Generation Z usually spends less than $10 \%$ under this head, followed by Generation Y spends either lees $10 \%$ or $10-20 \%$, and Generation Z usually spending $10-20 \%$. thus, people tend to spend more on Housing \& Utilities with increase in age. (Refer Table 5)Food - Usually the spending on Food remains constant across generations at around 10-20\%. (Refer Table 5)Apparel \& Personal Care The spending on this head usually lies in the less than $10 \%$ bracket. The only exception is when it rises to $10-20 \%$ for some respondents of Generation Y. It can be said that spending on Apparel \& Personal Care first increases with age, but later falls. (Refer Table 5)

Table 5: Income Utilization * Generation Cross-tabulation

\begin{tabular}{|c|c|c|c|c|}
\hline & & $\begin{array}{c}\text { Generatio } \\
\text { n Z }\end{array}$ & $\begin{array}{c}\text { Generatio } \\
\text { n Y }\end{array}$ & $\begin{array}{c}\text { Generatio } \\
\text { n X }\end{array}$ \\
\hline \multirow{5}{*}{$\begin{array}{c}\text { Housing \& } \\
\text { Utilities }\end{array}$} & $\begin{array}{l}\text { Less than } \\
10 \%\end{array}$ & 21 & 29 & 4 \\
\hline & $10-20 \%$ & 13 & 22 & 9 \\
\hline & $20-30 \%$ & 10 & 10 & 3 \\
\hline & $30-40 \%$ & 4 & 8 & 2 \\
\hline & $40-50 \%$ & 2 & 3 & 0 \\
\hline \multirow{6}{*}{ Food } & $\begin{array}{l}\text { Less than } \\
10 \%\end{array}$ & 7 & 18 & 7 \\
\hline & $10-20 \%$ & 19 & 31 & 5 \\
\hline & $20-30 \%$ & 9 & 16 & 4 \\
\hline & $30-40 \%$ & 9 & 1 & 2 \\
\hline & $40-50 \%$ & 3 & 5 & 0 \\
\hline & $\begin{array}{l}\text { Above } \\
50 \%\end{array}$ & 3 & 1 & 0 \\
\hline \multirow{6}{*}{$\begin{array}{c}\text { Apparel \& } \\
\text { Personal } \\
\text { Care }\end{array}$} & $\begin{array}{l}\text { Less than } \\
10 \%\end{array}$ & 19 & 32 & 10 \\
\hline & $10-20 \%$ & 12 & 31 & 6 \\
\hline & $20-30 \%$ & 11 & 6 & 1 \\
\hline & $30-40 \%$ & 4 & 1 & 1 \\
\hline & $40-50 \%$ & 2 & 2 & 0 \\
\hline & $\begin{array}{c}\text { Above } \\
50 \% \\
\end{array}$ & 2 & 0 & 0 \\
\hline \multirow{6}{*}{$\begin{array}{c}\text { Entertainm } \\
\text { ent }\end{array}$} & $\begin{array}{l}\text { Less than } \\
10 \%\end{array}$ & 23 & 39 & 11 \\
\hline & $10-20 \%$ & 12 & 19 & 6 \\
\hline & $20-30 \%$ & 9 & 11 & 1 \\
\hline & $30-40 \%$ & 4 & 0 & 0 \\
\hline & $40-50 \%$ & 1 & 3 & 0 \\
\hline & $\begin{array}{l}\text { Above } \\
50 \%\end{array}$ & 1 & 0 & 0 \\
\hline \multirow{6}{*}{ Education } & $\begin{array}{l}\text { Less than } \\
10 \%\end{array}$ & 18 & 26 & 4 \\
\hline & $10-20 \%$ & 10 & 22 & 7 \\
\hline & $20-30 \%$ & 14 & 10 & 4 \\
\hline & $30-40 \%$ & 5 & 10 & 2 \\
\hline & $40-50 \%$ & 1 & 4 & 1 \\
\hline & $\begin{array}{l}\text { Above } \\
50 \%\end{array}$ & 2 & 0 & 0 \\
\hline Saving & $\begin{array}{l}\text { Less than } \\
10 \%\end{array}$ & 8 & 13 & 4 \\
\hline
\end{tabular}




\section{Generational Differences in Personal Finance Behaviour - A Insight into Investors in Kolkata}

\begin{tabular}{|l|l|c|c|c|}
\hline & $10-20 \%$ & 10 & $\mathbf{1 4}$ & $\mathbf{5}$ \\
\cline { 2 - 5 } & $20-30 \%$ & $\mathbf{1 5}$ & $\mathbf{1 4}$ & 4 \\
\cline { 2 - 5 } & $30-40 \%$ & 9 & 9 & 1 \\
\cline { 2 - 5 } & $40-50 \%$ & 3 & 10 & 4 \\
\cline { 2 - 5 } & $\begin{array}{l}\text { Above } \\
50 \%\end{array}$ & 5 & 12 & 0 \\
\hline
\end{tabular}

Entertainment - Usually the spending on Entertainment remains constant across generations at less than $10 \%$. (Refer Table 5)Education - The spending on Education is less than $10 \%$ for Generation Z, either less than $10 \%$ or $10-20 \%$ for Generation Y, and 10-20\% for Generation X. This means that the spending on Education rises with age as the respondents' children grow. (Refer Table 5)Saving - Majority of Generation Z save $20-30 \%$ of their income, which is either $10-20 \%$ or $20-30 \%$ for Generation $Y$, and $10-20 \%$ for Generation $\mathrm{X}$. This is because, with increase in age the spending of the respondents increases and thus their saving falls. (Refer Table 5)

\section{Factor Analysis}

A principal component analysis was conducted on 28 items with orthogonal rotation (varimax) to find out the factors contributing to personal finance behaviour. The Kaiser-Meyer-Olkin (KMO) measure showed a value of 0.888 verifying sampling adequacy. Bartlett's test of sphericity showed $\chi^{2}(378)=2669.091$ and $\mathrm{p}<0.001$ verifying that the sample large enough for conducting a principal component analysis. (Refer Table 6)

Table 6: KMO and Bartlett's Test

\begin{tabular}{|l|l|r|}
\hline \multicolumn{2}{|l|}{ Kaiser-Meyer-Olkin Measure of Sampling Adequacy } & $\mathbf{. 8 8 8}$ \\
\hline $\begin{array}{l}\text { Bartlett's Test of } \\
\text { Sphericity }\end{array}$ & Approx. Chi-Square & 2669.091 \\
\cline { 2 - 3 } & df & 378 \\
\cline { 2 - 3 } & Sig. & $\mathbf{. 0 0 0}$ \\
\hline
\end{tabular}

An analysis was run to obtain eigenvalues for each component. Six components were found with eigenvalues more than 1, and they could together explain $70.601 \%$ of the variance. These six components were retained in the final analysis. (Refer Table 7)

Table 7: Total Variance Explained

\begin{tabular}{|c|c|c|c|c|c|c|}
\hline $\begin{array}{c}\text { Com } \\
\text { pone } \\
\text { nt }\end{array}$ & \multicolumn{2}{|c|}{$\begin{array}{c}\text { Initial } \\
\text { Eigenvalues }\end{array}$} & \multicolumn{2}{c|}{$\begin{array}{c}\text { Extraction } \\
\text { Sums of } \\
\text { Squared } \\
\text { Loadings }\end{array}$} & \multicolumn{2}{c|}{$\begin{array}{c}\text { Rotation Sums of } \\
\text { Squared } \\
\text { Loadings }\end{array}$} \\
\hline & Total & $\begin{array}{c}\text { \% of } \\
\text { Varian } \\
\text { ce }\end{array}$ & Total & $\begin{array}{c}\text { \% of } \\
\text { Varian } \\
\text { ce }\end{array}$ & Total & $\begin{array}{c}\text { \% of } \\
\text { Varianc } \\
\text { e }\end{array}$ \\
\hline 1 & 10.68 & 38.155 & $\begin{array}{c}10.68 \\
3\end{array}$ & 38.155 & 4.479 & 15.995 \\
\hline 2 & 3.302 & 11.793 & 3.302 & 11.793 & 4.402 & 15.723 \\
\hline 3 & 2.262 & 8.079 & 2.262 & 8.079 & 3.944 & 14.085 \\
\hline 4 & 1.373 & 4.902 & 1.373 & 4.902 & 2.493 & 8.902 \\
\hline 5 & 1.136 & 4.056 & 1.136 & 4.056 & 2.435 & 8.698 \\
\hline 6 & 1.012 & 3.616 & 1.012 & 3.616 & 2.016 & 7.199 \\
\hline \multicolumn{7}{|c|}{ Extraction Method: Principal Component Analysis. } \\
\hline
\end{tabular}

The items that cluster around the components suggest its name. The 6 items in Factor 1 represents 'Financial Planning', the 5 items in Factor 2 represents 'Use of Technology',the 8 items in Factor 3 represents 'Financial Independence', the 3 items in Factor 4 represents 'Financial Irresponsibility',the 4 items in Factor 5 represents 'Financial Openness', and the 2 items in Factor 6 represents 'Use of Credit Cards'. These were the 6 factors found to be contributing to the respondents' personal finance behaviour. (Refer Table 8)

Table 8: Summary of Factor Analysis

\begin{tabular}{|c|c|c|c|c|c|c|}
\hline Factors & $\begin{array}{c}\text { Eige } \\
\text { nval } \\
\text { ues }\end{array}$ & $\begin{array}{c}\text { \% of } \\
\text { Varia } \\
\text { nce } \\
\text { Expla } \\
\text { ined }\end{array}$ & $\begin{array}{l}\text { Numb } \\
\text { er of } \\
\text { Items } \\
\text { Cluste } \\
\text { red }\end{array}$ & $\begin{array}{l}\text { Score } \\
\text { for } \\
\text { Gene } \\
\text { ratio } \\
\text { n Z }\end{array}$ & $\begin{array}{l}\text { Score } \\
\text { for } \\
\text { Gene } \\
\text { ratio } \\
\text { n Y }\end{array}$ & $\begin{array}{l}\text { Scor } \\
\text { e for } \\
\text { Gen } \\
\text { erati } \\
\text { on } X\end{array}$ \\
\hline $\begin{array}{l}\text { Financial } \\
\text { Planning }\end{array}$ & 4.479 & $\begin{array}{r}15.99 \\
5\end{array}$ & 6 & 19.70 & 20.39 & $\begin{array}{r}22.3 \\
9 \\
\end{array}$ \\
\hline $\begin{array}{l}\text { Use of } \\
\text { Technology }\end{array}$ & 4.402 & $\begin{array}{r}15.72 \\
3 \\
\end{array}$ & 5 & 19.72 & 19.75 & $\begin{array}{r}18.8 \\
9 \\
\end{array}$ \\
\hline $\begin{array}{l}\text { Financial } \\
\text { Independenc } \\
\text { e }\end{array}$ & 3.944 & $\begin{array}{r}14.08 \\
5\end{array}$ & 8 & 30.08 & 31.60 & $\begin{array}{r}30.7 \\
8\end{array}$ \\
\hline $\begin{array}{l}\text { Financial } \\
\text { Irresponsibil } \\
\text { ity }\end{array}$ & 2.493 & 8.902 & 3 & 7.60 & 8.81 & 9.39 \\
\hline $\begin{array}{l}\text { Financial } \\
\text { Openness }\end{array}$ & 2.435 & 8.698 & 4 & 13.38 & 13.95 & $\begin{array}{r}14.6 \\
1\end{array}$ \\
\hline $\begin{array}{l}\text { Use of } \\
\text { Credit Cards }\end{array}$ & 2.016 & 7.199 & 2 & 5.94 & 5.80 & 6.27 \\
\hline Total & & $\begin{array}{r}70.60 \\
1 \\
\end{array}$ & 28 & & & \\
\hline \multicolumn{6}{|c|}{ Kaiser-Meyer-Olkin Measure of Sampling Adequacy } & $\begin{array}{r}0.88 \\
8\end{array}$ \\
\hline \multicolumn{6}{|c|}{ Bartlett's Test of Sphericity (Sig.) } & $\begin{array}{r}0.00 \\
0\end{array}$ \\
\hline
\end{tabular}

\section{Comparison of These 6 Factors Across Generations}

- Financial Planning Across Generations: It can be observed that Generation $X$ has the highest Financial Planning score followed by Generation Y and then by Generation X. The individual items also portray the same, with the exception of 'I add to my savings monthly' which is high for Generation Z and X. (Refer Table 9)

Table 9: Financial Planning (Mean Scores)

\begin{tabular}{|l|r|r|r|}
\hline & \multicolumn{1}{|c|}{$\begin{array}{c}\text { Generati } \\
\text { on Z }\end{array}$} & \multicolumn{1}{c|}{$\begin{array}{c}\text { Generati } \\
\text { on Y }\end{array}$} & \multicolumn{1}{c|}{$\begin{array}{c}\text { Generati } \\
\text { on X }\end{array}$} \\
\hline $\begin{array}{l}\text { I am saving enough for my } \\
\text { future }\end{array}$ & 3.18 & 3.43 & 3.72 \\
\hline $\begin{array}{l}\text { I think my insurance } \\
\text { policies meet my protection } \\
\text { needs }\end{array}$ & 3.36 & 3.32 & 3.56 \\
\hline $\begin{array}{l}\text { I have a plan to provide for } \\
\text { my child's education }\end{array}$ & 2.94 & 3.21 & 3.83 \\
\hline I add to my savings monthly & 4.02 & 3.79 & 4.06 \\
\hline $\begin{array}{l}\text { I make investments in order } \\
\text { to reduce my tax burden }\end{array}$ & 3.24 & & 3.54 \\
\hline $\begin{array}{l}\text { I have enough money to } \\
\text { cover unforeseen } \\
\text { emergencies }\end{array}$ & & & 3.72 \\
\hline Total (out of 30) & $\mathbf{1 9 . 7}$ & $\mathbf{2 0 . 3 9}$ & $\mathbf{2 2 . 3 9}$ \\
\hline
\end{tabular}

- Use of Technology Across Generations: Generation Z and Generation Y can be both seen to use more technology in personal finance than Generation X. This behaviour is present throughout the 5 items, and is mostly due to younger generations being more tech savvy. (Refer Table 10)

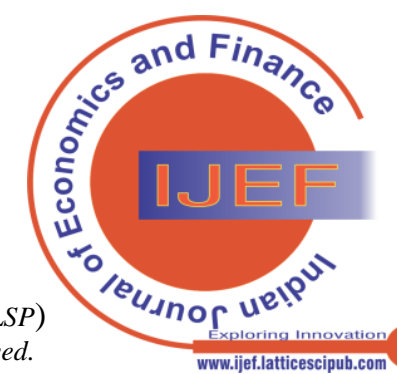


Table 10: Use of Technology (Mean Scores)

\begin{tabular}{|l|r|r|r|}
\hline & \multicolumn{1}{|c|}{$\begin{array}{r}\text { Generat } \\
\text { ion Z }\end{array}$} & \multicolumn{1}{|c|}{$\begin{array}{c}\text { Genera } \\
\text { tion Y }\end{array}$} & \multicolumn{1}{c|}{$\begin{array}{c}\text { Genera } \\
\text { tion X }\end{array}$} \\
\hline $\begin{array}{l}\text { I transfer money using mobile } \\
\text { banking apps }\end{array}$ & 3.86 & 3.81 & 3.78 \\
\hline $\begin{array}{l}\text { I often use a mobile app for } \\
\text { transactions }\end{array}$ & 4 & 3.93 & 3.89 \\
\hline $\begin{array}{l}\text { I use mobile apps to make utility } \\
\text { bill payments }\end{array}$ & 4.7 & 3.96 & 3.72 \\
\hline I prefer receiving payments \\
online
\end{tabular}

- Financial Independence Across Generations: It can be seen here that Generation Y is the most financially independent. It fares well on almost all items, with the exception of 'I can manage my own financial affairs' where Generation X fares better. (Refer Table 11)

Table 11: Financial Independence (Mean Scores)

\begin{tabular}{|l|r|r|r|}
\hline & \multicolumn{1}{|c|}{$\begin{array}{c}\text { Genera } \\
\text { tion Z }\end{array}$} & \multicolumn{1}{|c|}{$\begin{array}{c}\text { Genera } \\
\text { tion Y }\end{array}$} & \multicolumn{1}{|c|}{$\begin{array}{c}\text { Generat } \\
\text { ion X }\end{array}$} \\
\hline $\begin{array}{l}\text { I don't trust others to make } \\
\text { financial decisions that affect my } \\
\text { future well-being }\end{array}$ & 3.72 & 3.67 & 3.5 \\
\hline $\begin{array}{l}\text { I think about my financial } \\
\text { commitments all the time }\end{array}$ & 3.74 & 4.03 & 3.67 \\
\hline $\begin{array}{l}\text { I can manage my own financial } \\
\text { affairs (e.g., taxes, investments, } \\
\text { savings) }\end{array}$ & 3.28 & 3.61 & 3.89 \\
\hline $\begin{array}{l}\text { I don't want to rely on my parents } \\
\text { financially }\end{array}$ & 4.06 & 4.26 & 4.06 \\
\hline $\begin{array}{l}\text { I will reach financial } \\
\text { independence before I reach age } \\
\text { 60 }\end{array}$ & 4.2 & 4.19 & 3.89 \\
\hline $\begin{array}{l}\text { I don't expect social security and } \\
\text { company retirement plans to } \\
\text { adequately meet my retirement } \\
\text { needs }\end{array}$ & & & 3.96 \\
\hline $\begin{array}{l}\text { I am taking steps now to plan for } \\
\text { my future well-being }\end{array}$ & 3.16 & 3.75 & 3.18 \\
\hline $\begin{array}{l}\text { I prepare a monthly budget for my } \\
\text { expenses }\end{array}$ & $\mathbf{3 0 . 0 8}$ & $\mathbf{3 1 . 6}$ & 3.9 .78 \\
\hline Total (out of 40) & & & \\
\hline
\end{tabular}

- Financial Irresponsibility Across Generations: It is observed that Generation X is the most irresponsible, whereas Generation $\mathrm{Z}$ is the least irresponsible. The scores of all 3 items show the same. (Refer Table 12)

Table 12: Financial Irresponsibility (Mean Scores)

\begin{tabular}{|l|r|r|r|}
\hline & \multicolumn{1}{|c|}{$\begin{array}{c}\text { Genera } \\
\text { tion Z }\end{array}$} & \multicolumn{1}{c|}{$\begin{array}{c}\text { Genera } \\
\text { tion Y }\end{array}$} & $\begin{array}{c}\text { Generati } \\
\text { on X }\end{array}$ \\
\hline I sometimes pay late payment fees & 2.42 & 2.65 & 2.78 \\
\hline $\begin{array}{l}\text { I rarely make efforts to reduce my } \\
\text { debt }\end{array}$ & 2.18 & 2.97 & 3.17 \\
\hline I prefer buying electronics on EMI & 3 & 3.19 & 3.44 \\
\hline Total (out of 15) & $\mathbf{7 . 6}$ & $\mathbf{8 . 8 1}$ & $\mathbf{9 . 3 9}$ \\
\hline
\end{tabular}

- Financial Openness Across Generations: It can be seen that Generation $X$ is the most financially open followed by Generation Y, and then Generation Z. Generation X gets a higher score for all items except 'I prefer e-wallets over banking apps for quick transfer', where Generation Y fares better. (Refer Table 13)

\section{Table 13: Financial Openness (Mean Scores)}

\begin{tabular}{|l|r|r|r|}
\hline & $\begin{array}{c}\text { Genera } \\
\text { tion Z }\end{array}$ & \multicolumn{1}{|c|}{$\begin{array}{c}\text { Genera } \\
\text { tion Y }\end{array}$} & \multicolumn{1}{c|}{$\begin{array}{c}\text { Generat } \\
\text { ion X }\end{array}$} \\
\hline $\begin{array}{l}\text { I prefer using a desktop for online } \\
\text { banking }\end{array}$ & 3.36 & 3.33 & 3.56 \\
\hline $\begin{array}{l}\text { I feel comfortable investing in } \\
\text { stocks or equity mutual funds }\end{array}$ & 3.2 & 3.39 & 3.83 \\
\hline $\begin{array}{l}\text { I prefer e-wallets over banking } \\
\text { apps for quick transfer }\end{array}$ & 3.48 & 3.72 & 3.33 \\
\hline $\begin{array}{l}\text { My generation is less fearful of } \\
\text { debt than our parents and } \\
\text { grandparents }\end{array}$ & 3.34 & 3.51 & 3.89 \\
\hline Total (out of 20) & $\mathbf{1 3 . 3 8}$ & $\mathbf{1 3 . 9 5}$ & $\mathbf{1 4 . 6 1}$ \\
\hline
\end{tabular}

- Use of Credit Cards Across Generations: Generation X is seen to use credit cards the most, followed by Generation $\mathrm{Z}$ and Generation Y. This behaviour is also portrayed by the individual items. (Refer Table 14)

Table 14: Use of Credit Cards (Mean Scores)

\begin{tabular}{|l|r|r|r|}
\hline & \multicolumn{1}{|c|}{$\begin{array}{c}\text { Generat } \\
\text { ion Z }\end{array}$} & $\begin{array}{c}\text { Generati } \\
\text { on Y }\end{array}$ & \multicolumn{1}{c|}{$\begin{array}{c}\text { Generat } \\
\text { ion X }\end{array}$} \\
\hline $\begin{array}{l}\text { I pay majority of my expenses } \\
\text { using credit cards }\end{array}$ & 2.7 & 2.74 & 2.94 \\
\hline $\begin{array}{l}\text { I am comfortable using credit } \\
\text { cards }\end{array}$ & 3.24 & 3.06 & 3.33 \\
\hline Total (out of 10) & $\mathbf{5 . 9 4}$ & $\mathbf{5 . 8}$ & $\mathbf{6 . 2 7}$ \\
\hline
\end{tabular}

\section{CONCLUSION}

It can be concluded that younger generations invest for the objective of keeping funds for emergency purposes, whereas older generations invest for their retirement needs. Younger generations usually invest for the short run, whereas older generations invest for the long run. Also, younger generations invest in easily accessible and popular investment avenues, whereas older invest in the most effective avenue. (Refer Table 15)

Table 15: Summary of Personal Finance Variables Across Generations

\begin{tabular}{|l|l|l|l|}
\hline & $\begin{array}{c}\text { Generation } \\
\mathbf{Z}\end{array}$ & Generation Y & Generation X \\
\hline $\begin{array}{l}\text { Most } \\
\text { Preferred } \\
\text { Purpose of } \\
\text { Investment }\end{array}$ & Emergencies & $\begin{array}{l}\text { Emergencies, } \\
\text { Retirement }\end{array}$ & \\
\hline $\begin{array}{l}\text { Most } \\
\text { Preferred } \\
\text { Time }\end{array}$ & & Retirement Needs \\
Horizon & $1-3$ years & $\begin{array}{l}\text { 1- 3 years, } 3- \\
5 \text { years }\end{array}$ & Above 10 years \\
\hline $\begin{array}{l}\text { Most } \\
\text { Preferred } \\
\text { Investment } \\
\text { Avenue }\end{array}$ & Fixed Deposit & $\begin{array}{l}\text { Fixed Deposit, } \\
\text { Mutual Fund }\end{array}$ & Mutual Fund \\
\hline
\end{tabular}

It was also concluded that spending on housing \& utilities increase with age, spending on food remains constant, spending on apparel \& personal care first increases but later decreases with age, 


\section{Generational Differences in Personal Finance Behaviour - A Insight into Investors in Kolkata}

spending on entertainment remains constant, sending on education increases with age, and saving decreases with age. (Refer Table 16)

\section{Table 16: Summary of Income Utilization Across} Generations

\begin{tabular}{|c|c|c|c|}
\hline & $\begin{array}{c}\text { Generati } \\
\text { on Z } \\
\end{array}$ & $\begin{array}{c}\text { Generati } \\
\text { on Y }\end{array}$ & $\begin{array}{c}\text { Generation } \\
\text { X }\end{array}$ \\
\hline $\begin{array}{l}\text { Usual Spending on } \\
\text { Housing \& Utilities }\end{array}$ & $\begin{array}{l}\text { Less than } \\
10 \%\end{array}$ & $\begin{array}{l}\text { Less than } \\
10 \%, 10 \text { - } \\
20 \%\end{array}$ & $10-20 \%$ \\
\hline Usual Spending on Food & $10-20 \%$ & $10-20 \%$ & $10-20 \%$ \\
\hline $\begin{array}{l}\text { Usual Spending on } \\
\text { Apparel \& Personal Care }\end{array}$ & $\begin{array}{l}\text { Less than } \\
10 \%\end{array}$ & $\begin{array}{l}\text { Less than } \\
10 \%, 10 \text { - } \\
20 \%\end{array}$ & $\begin{array}{l}\text { Less than } \\
10 \%\end{array}$ \\
\hline $\begin{array}{l}\text { Usual Spending on } \\
\text { Entertainment }\end{array}$ & $\begin{array}{l}\text { Less than } \\
10 \%\end{array}$ & $\begin{array}{l}\text { Less than } \\
10 \%\end{array}$ & $\begin{array}{l}\text { Less than } \\
10 \%\end{array}$ \\
\hline $\begin{array}{l}\text { Usual Percentage of } \\
\text { Saving }\end{array}$ & $20-30 \%$ & $\begin{array}{l}10-20 \%, \\
20-30 \%\end{array}$ & $10-20 \%$ \\
\hline & $\begin{array}{c}\text { Generati } \\
\text { on Z }\end{array}$ & $\begin{array}{l}\text { Generati } \\
\text { on Y }\end{array}$ & $\begin{array}{c}\text { Generation } \\
\text { X }\end{array}$ \\
\hline $\begin{array}{l}\text { Usual Spending on } \\
\text { Housing \& Utilities } \\
\end{array}$ & $\begin{array}{l}\text { Less than } \\
10 \%\end{array}$ & $\begin{array}{l}\text { Less than } \\
10 \%, 10- \\
20 \%\end{array}$ & $10-20 \%$ \\
\hline Usual Spending on Food & $10-20 \%$ & $10-20 \%$ & $10-20 \%$ \\
\hline $\begin{array}{l}\text { Usual Spending on } \\
\text { Apparel \& Personal Care }\end{array}$ & $\begin{array}{l}\text { Less than } \\
10 \%\end{array}$ & $\begin{array}{l}\text { Less than } \\
10 \%, 10 \text { - } \\
20 \%\end{array}$ & $\begin{array}{l}\text { Less than } \\
10 \%\end{array}$ \\
\hline $\begin{array}{l}\text { Usual Spending on } \\
\text { Entertainment }\end{array}$ & $\begin{array}{l}\text { Less than } \\
10 \%\end{array}$ & $\begin{array}{l}\text { Less than } \\
10 \%\end{array}$ & $\begin{array}{l}\text { Less than } \\
10 \%\end{array}$ \\
\hline $\begin{array}{l}\text { Usual Percentage of } \\
\text { Saving }\end{array}$ & $20-30 \%$ & $\begin{array}{l}10-20 \%, \\
20-30 \%\end{array}$ & $10-20 \%$ \\
\hline
\end{tabular}

The 28 items had clustered around six factors namely, Financial Planning, Use of Technology, Financial Independence, Financial Irresponsibility, Financial Openness and Use of Credit Cards. It was found that Generation X has the highest score in Financial Planning, Generation $\mathrm{Z}$ and $\mathrm{Y}$ had high scores in Use of Technology, Generation $\mathrm{Y}$ in Financial Independence, Generation $\mathrm{X}$ in Financial Irresponsibility, Generation X in Financial Openness, and also Generation X in Use of Credit Cards. (ReferTable8)

\section{REFERENCES}

1. Ameritrade. (2016). Millennials and Money Research: Understanding attitudes \& behaviors toward saving and. Omaha: Ameritrade.

2. Bauer, D. L., Collins, D. T., \& Richardson, K. (2017). Attitudes about Financial Wealth: Generational Comparisons of Gen-Xers vs. Millennials. Journal of Business \& Economic Policy, 4(2), 30-35.

3. Carlin, B., Olafsson, A., \& Pagel, M. (2019). Fintech Adoption Across Generations: Financial Fitness in the Information Age. American Economic Association: Annual Meeting 2019 (pp. 1-57). Atlanta: American Economic Association.

4. Carlin, B., Olafsson, A., \& Pagel, M. (2019). Generational Differences in Managing Personal Finances. American Economic Association: Papers and Proceedings (pp. 54-59). American Economic Association. [CrossRef]

5. Columbia ThreadNeedle Investments. (2020). How Different Generations Are Adapting to a New Financial Future. London: Columbia ThreadNeedle Investments.

6. Deventer, M. v. (2020). African Generation Y students' personal finance behavior and knowledge. Investment Management and Financial Innovations, 17(4), 136-144. [CrossRef]

7. Horan, S. (2020, January 16). How Different Generations Spend Money. Retrieved from Smart Asset: https://smartasset.com/checking-account/how-different-generationsspend-money-2020
8. Kurz, C., Li, G., \& Vine, D. J. (2018). Are Millennials Different? Finance and Economics Discussion Series (pp. 1-56). Board of Governors of the Federal Reserve System. [CrossRef]

9. Luther, R., Coleman, L. J., Kelkar, M., \& Foudray, G. (2018) Generational differences in perceptions of financial planners. Journal of Financial Services Marketing, 23, 112-127. [CrossRef]

10. Scheresberg, C. d., \& Lusardi, A. (2014). Gen Y Personal Finances: A Crisis of Confidence and Capability. Madison: Filene Research Institute.

11. Sulphey, M. M., \& Faisal, S. (2020). Generational difference as predictors of financial behaviour. International Journal of Electronic Marketing and Retailing, 11(4), 369-383. [CrossRef]

\section{AUTHORS PROFILE}

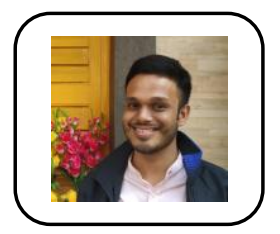

Risav Adhikari is currently a Faculty Member in Management, at St. Xavier's University, Kolkata. He is also pursuing Ph.D. in Behavioral Finance from St. Xavier's College, Kolkata. His research interests are in Behavioral Finance and Financial Literacy. He has cleared UGC NET (with JRF) and qualified West Bengal SET in Commerce.

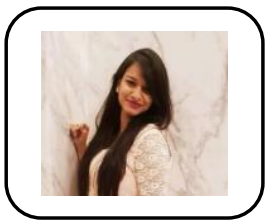

Shiwangi Poddar is currently a Faculty Member in Management, at St. Xavier's University, Kolkata. Her research interest is in Marketing, and specifically Generational Marketing. She has cleared UGC NET in Commerce. She has previously taught in JD Birla Institute, Kolkata and Shri Shikshayatan College, Kolkata.

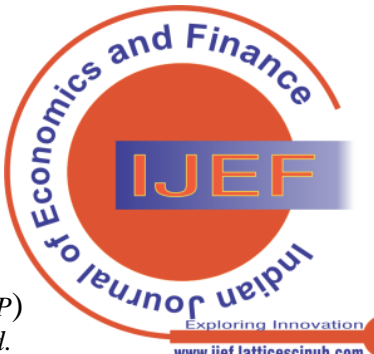

